\title{
A new species of Terebellides (Polychaeta: Trichobranchidae) from Scottish waters with an insight into branchial morphology
}

\author{
J. Parapar ${ }^{1}$, J. Moreira $^{2}$, M. O’Reilly ${ }^{3}$
}

1 Departamento de Bioloxía Animal, Bioloxía Vexetal e Ecoloxía, Universidade da Coruña, 15008 A Coruña, Spain jparapar@udc.es

2 Departamento de Biología (Zoología), Facultad de Ciencias, Universidad Autónoma de Madrid, Cantoblanco, E-28049 Madrid, Spain

3 Scottish Environment Protection Agency, Angus Smith Building, 6 Parklands Avenue, Eurocentral, Holytown, North Lanarkshire ML1 4WQ, Scotland, UK

Marine Biodiversity, March 2016, Volume 46, Issue 1, pp 211-225

Received: 25 August 2014 /Revised: 31 March 2015 /Accepted: 5 June 2015 /Published online: 27 June 2015

(c) Senckenberg Gesellschaft für Naturforschung and Springer-Verlag Berlin Heidelberg 2015

Cite this article as: Parapar, J., Moreira, J. \& O'Reilly, M. Mar Biodiv (2016) 46: 211. doi:10.1007/s12526-015-0353-5

The final publication is available at Springer via http://dx.doi.org/10.1007/s12526-015-0353-5

\begin{abstract}
Based on specimens collected during several sampling programmes mainly in the northern North Sea, Scotland, a new species of the genus Terebellides (Polychaeta; Trichobranchidae) was found and described herein as Terebellides shetlandica spec. nov. The new species is primarily characterised by the presence of a long pointed posterior filament in the ventral branchial lobes. The species is compared with other Terebellides species described or reported from North Atlantic waters, and an updated key to the Terebellides species of the North East Atlantic and Mediterranean Sea is provided. The presence of copepods of the genus Melinnacheres attached to the thorax of this species is reported. Morphology of T. shetlandica spec. nov. was also studied with SEM and micro-CT. Branchial characters used in the taxonomy of the genus are reviewed and four general branchial types are defined.
\end{abstract}




\section{Keywords}

NE Atlantic Ocean; Terebellides shetlandica spec. nov; Parasitic copepod; Morphology; Branchiae; Micro-CT

\section{Introduction}

The genus Terebellides Sars 1835 is the largest within the family Trichobranchidae Sars 1835 and has currently 51 valid species (Schüller and Hutchings 2013). Traditionally, the genus is diagnosed by having four-lobed branchiae as a single mid-dorsal stalked structure on the third segment; some authors, however, consider the anterior prolongation of the dorsal lobes as a fifth lobe (e.g. Williams 1984; Solis-Weiss et al. 1991; Hutchings and Peart 2000; Garraffoni and Lana 2003; Schüller and Hutchings 2010, 2012, 2013; Parapar et al. 2011, 2013). The branchiae constitute a complex structure and are by far the most characteristic organ of the genus, showing great interspecific variability, being quite different from those of the remaining trichobranchid genera, namely Artacamella Hartman 1955, Trichobranchus Malmgren 1866 and Octobranchus Marion and Bobretzky 1875 [Unobranchus Hartman 1965 was recently demonstrated to be a senior synonym of Terebellides by Muir (2011)]. Surprisingly, accurate descriptions of the branchiae across Terebellides species are scarce and little attention has been paid to this relevant character for taxonomic issues.

Examination of the polychaete collection obtained during benthic surveys in several oilfields located near the Shetland Islands showed the presence of numerous Terebellides specimens with ectoparasitic copepods. The Terebellides hosts were initially identified as T. stroemii Sars 1835, this being the only species currently recorded from British Seas (see Holthe 1986; Howson and Picton 1997). The parasitised Terebellides were sent to one of us (MO'R) for closer examination of the copepods. At this point it was realised that the hosts differed from T. stroemii and they have now been shown to represent a new species to science. We provide the description of the new species, named herein as Terebellides shetlandica spec. nov., and provide an updated key to all species of the genus known to occur in North East Atlantic and Mediterranean waters. Furthermore, we conducted a detailed study of the external and internal body morphology of the new species, both using stereomicroscope, SEM and micro-CT, as well as a review of the characters traditionally used in the descriptions of Terebellides, identifying new features in the branchiae which may be worth considering in the description of this highly taxonomically relevant organ. Finally, the finding of parasitic copepods in a large number of specimens of $T$. shetlandica spec. nov., has led us to provide a brief note regarding infestation by ectoparasitic copepods in polychaetes, as these have been poorly reported in the literature. A fuller account of the copepods from Terebellides is being undertaken as a separate publication (O'Reilly 2015). 


\section{Material and methods}

This study is based on material most of which was collected during routine benthic macrofaunal monitoring surveys of several oilfields in the northern North Sea, Scotland in 1991, 2008 and 20102012. A total of 14 specimens belonging to a new species of the genus Terebellides were collected at nine stations sampled with a Day Grab mostly from east of the Shetland Islands, but one specimen was recovered from near the Western Isles, Scotland, and two specimens from the Western Approaches off south west England. Specimens were fixed in $4 \%$ formalin, preserved in $70 \%$ ethanol and sorted by various sub-contractors before being transferred to MO'R at the Scottish Environment Protection Agency (SEPA) and these and additional material was subsequently sent to JP (Universidade da Coruña-UDC, Spain). The holotype and several paratypes were deposited in the Zoological collection of the National Museum of Scotland (NMS.Z); other paratypes were also deposited in the collections of the Natural History Museum of London (NHM) and Museo Nacional de Ciencias Naturales of Madrid (MNCN).

Two specimens used for examination with Scanning Electron Microscopy (SEM) were prepared by critical point drying, covered with gold and examined and photographed at the Servicios de Apoio á Investigación-SAI (Universidade da Coruña-UDC, Spain). The specimen studied with the micro-CT scan at the Marine Biology Station of A Graña (University of Santiago de Compostela-USC, Spain) was originally preserved in ethanol $80 \%$ and dehydrated in successive baths of ethanol $90 \%$ and $96 \%$, then immersed for 2 hours in hexamethyldisilazane (HMDS) and allowed to air dry overnight (Alba-Tercedor and Sánchez-Tocino 2011; Faulwetter et al. 2013).

Methyl green (MG) staining patterns were determined based on the classification proposed by Schüller and Hutchings (2010).

Abbreviations used in the text: $C H$ chaetiger, $d g$ digestive gland, $F I$ fore intestine, $F S$ fore stomach, $f s l$ fore stomach lumen, $H S$ hind stomach, $h s w$ hind stomach wall, $O E$ oesophagus, php pharyngeal pouch, $S G$ segment, $T C$ thoracic chaetiger.

\section{Results}

A total of 14 specimens of Terebellides shetlandica spec. nov. were collected at eight stations in north Scotland, and one off south west England, in 1991, 2008 and 2010-2012. External and gross internal morphology was studied in detail under the stereomicroscope, SEM and micro-CT, and the description of the new species is provided below. Furthermore, several specimens of other species of Terebellides were examined for comparative purposes. The presence of the ectoparasitic copepod Melinnacheres terebellidis (Levinsen 1878) whenever attached to specimens of T. shetlandica spec. nov. is also reported. 


\section{Taxonomy}

Family TRICHOBRANCHIDAE Malmgren 1866

Genus Terebellides Sars 1865, emended by Schüller and Hutchings 2013

Type species. - Terebellides stroemii Sars 1835

Remarks. - Parapar et al. (2013) proposed to emend the diagnosis of the genus provided by Schüller and Hutchings (2013) by deleting the word "smooth" when referred to the thoracic geniculate chaetae. Parapar et al. (2013) based their emendation on the findings of Parapar et al. (2011), who had previously found on this special type of chaetae minute teeth forming a capitium, in all Icelandic Terebellides species they had examined. In the new species described herein, i.e. Terebellides shetlandica spec. nov., the teeth on the upper part of the geniculate chaetae are also present (see Description below).

Terebellides shetlandica spec. nov.

Type material. - NMS.Z 2013.07.01, holotype (with oocytes in body cavity; used for microCT), NW Hutton Oilfield, $61^{\circ} 10^{\prime} \mathrm{N}, 001^{\circ} 12^{\prime} \mathrm{E}, 1991,160 \mathrm{~m}$ water depth; NMS.Z 2013.07.02, 3 paratypes, Lyell Oilfield, 6053.94’N, 01¹6.29’E, July 1991, 140 m water depth; NMS.Z 2015.023.1, 1 paratype (with ovigerous female of Melinnacheres terebellidis attached), Unico 47556, survey GDL843510, Western Isles, Dev site 20-MFB, 15 July 2010; NMS.Z 2015.023.2, Unico 48091, survey GDL844210, Emerald Oilfield, Stn. EMD06-MFB, 22 September 2010; 2 paratypes (one with ovigerous female of $M$. terebellidis attached; other not parasitized); NMS.Z 2015.023.3, Unico 48097, survey GDL844210, Cheviot Oilfield, ENV02-MFA, 04 October 2012; 1 paratype (with ovigerous female of M. terebellidis attached); NMS.Z 2015.023.4, Unico 49251, survey GDL858410, South Gryphon Oilfield, Stn. SGG-F1-E-3-MFA, 14 January 2011 (cat. B01.204 M1174); 1 paratype (with ovigerous female of M. terebellidis attached); NHMUK ANEA 2015.201-202, Western Approaches, Haig Fras, Stn. 63 (approx. 50.5 N, 07.3 W), April-June 2011, 100 water m depth, coll. Steve Jarvis; 2 paratypes (both with ovigerous females of M. terebellidis attached); MNCN 16.01/16175, Apem Pr. 412613, Sa. 6292, Braemar Oilfield, Stn. BRMR01 24A; 1 paratype; NMS.Z 2015.023.5, SEM stub with 2 paratypes, from 2015.023.2 and NMS.Z 2015.023.3 (bigger one) respectively.

Comparative material. - Swedish Museum of Natural History: SMNH 6625, one specimen of Terebellides longicaudatus Hessle 1917, on SEM stub, South Georgia, Cumberland Bay, off May Bay, SSPE station $22,5^{\circ} 17^{\prime} \mathrm{S}, 36^{\circ} 28^{\prime} \mathrm{W}, 75 \mathrm{~m}$ water depth, clay, algae (source: Parapar and Moreira 2008). 
Natural History Museum Rijeka (Croatia): PMR-14573, one specimen of Terebellides stroemii Sars 1835, on SEM stub, Station LIM K5, 07 July 2010; PMR-14559, one specimen of Terebellides mediterranea Parapar et al. 2013, on SEM stub, Station SJ 007, 27 February 2003 (source: Parapar et al. 2013). Icelandic Institute of Natural History: IMNH 24931, one specimen of Terebellides gracilis

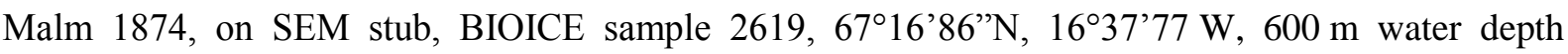
(source: Parapar et al. 2011).

Description (based on holotype and paratypes). - Complete individuals ranging from 6 to $15 \mathrm{~mm}$ in length (13 $\mathrm{mm}$ in holotype) and 0.4 to $1.5 \mathrm{~mm}$ in maximum width at thoracic region (0.9 $\mathrm{mm}$ in holotype). Body tapering posteriorly with segments increasingly shorter and crowded towards pygidium. Prostomium compact; large tentacular membrane surrounding the mouth usually devoid of buccal tentacles (Figs. 2a and 7). SGI forming an expanded structure below tentacular membrane (Fig. 1a, b). Lateral lappets on TC1-6 (SGIII-VIII), being larger in TC1-3 (Fig. 2c). No conspicuous dorsal rounded projection on anterior chaetigers or oval-shaped glandular region in TC3.

Fig. 1 Stereomicroscope images of several Terebellides shetlandica spec. nov. paratypes, all infected by the parasitic copepod Melinnacheres terebellinis (Levinsen 1878) (a) NMS.Z 2013.071.02 (stained with Bengal Rose); (b) NMS.Z 2015.023.2; (c) NHM 000; (d) NMS.Z 2015.023.3; (e) NHM 000; (f) NMSZ NMS.Z 2015.023.1. Abbreviations: $\mathrm{dl}=$ dorsal lobes; ov=ovisacs; $\mathrm{pc}=$ parasitic copepod; $\mathrm{pf}=$ posterior filament; $\mathrm{vl}=$ ventral lobes. In (a) and (f) ovisacs are lost

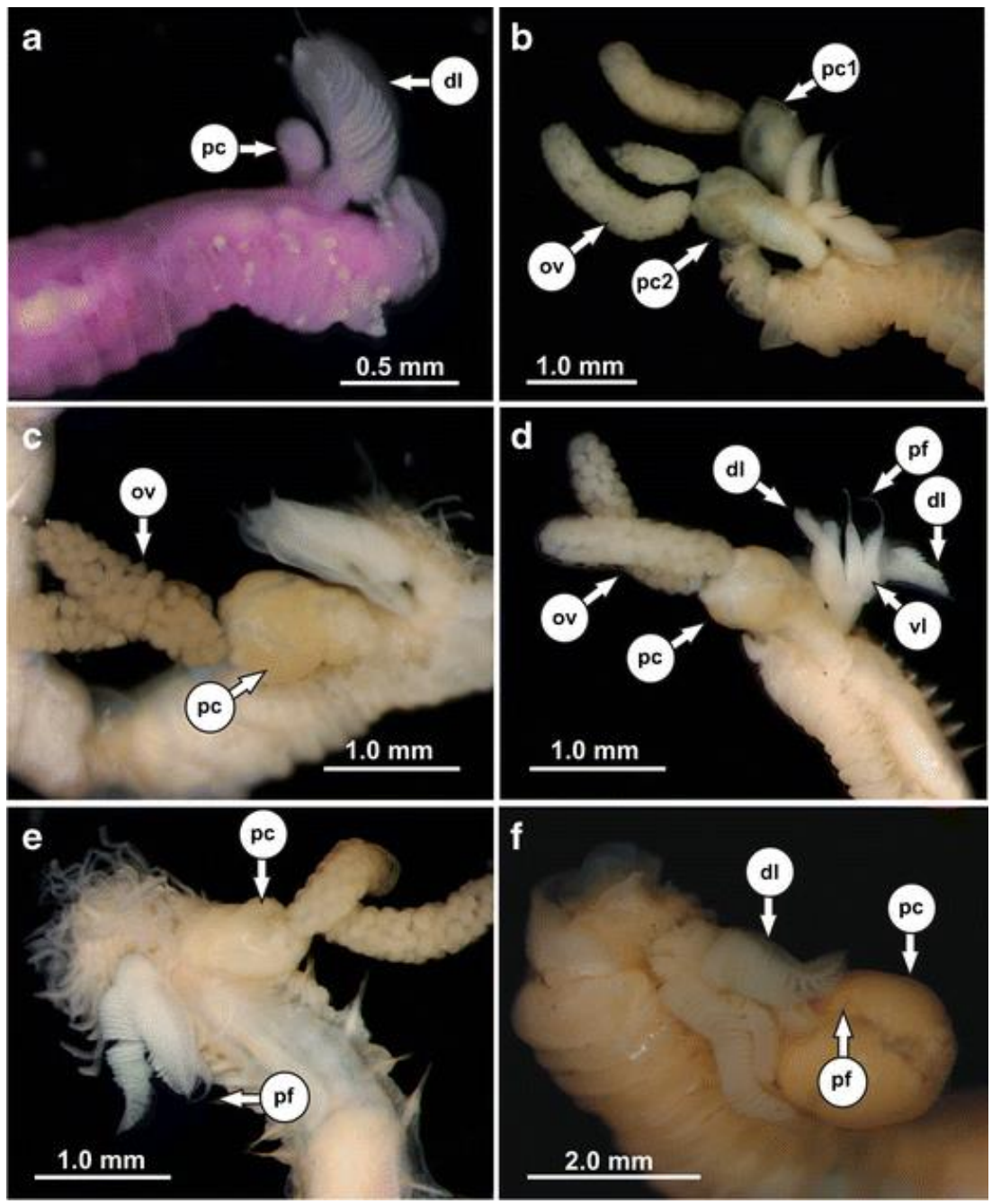


Fig. 2 Terebellides shetlandica spec. nov. (NMS.Z 2015.023.5) (a) anterior end, lateral view of a 3-lobed branchiae specimen; (b) detail of the lamellae ciliation of the dorsal lobe; (c) anterior end, latero-ventral view; (d) detail of dorsal part of TC1 to TC3; (e) detail of ciliary area of thoracic notopodial papilla; (f) detail of thoracic notopodial papilla openings. Abbreviations: lvl=left ventral lobe; $\mathrm{np}=$ nephridial pore; rdl=right dorsal lobe; rvl=right ventral lobe; $t d p=$ thoracic dorsal papillae; $\mathrm{TC}=$ thoracic chaetiger
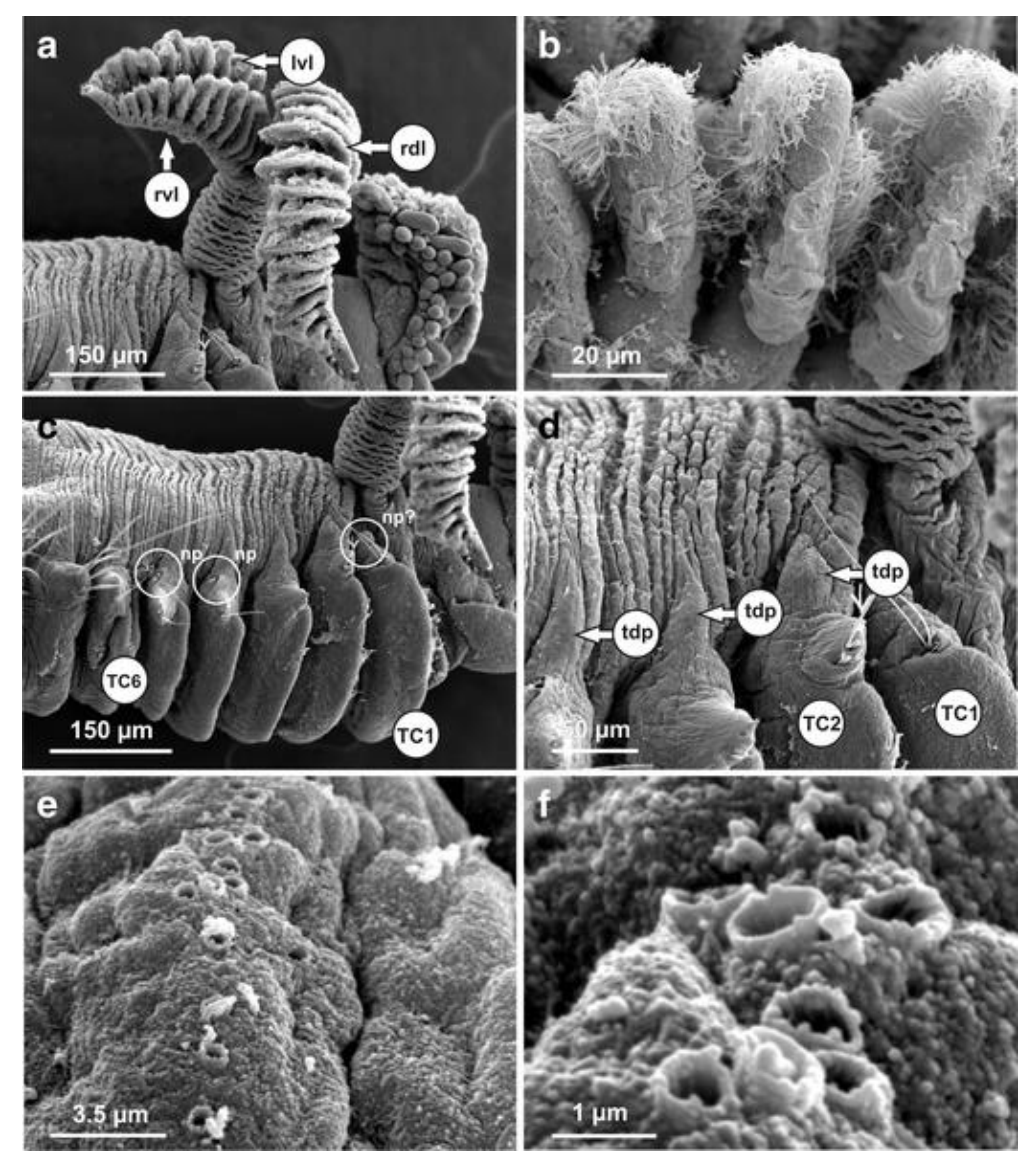

Branchiae arising as single structure from TC1 (SGIII) (Figs. 2a and 5a), consisting of a single stalked structure situated mid-dorsally and made up of two pairs of unfused lobes; lower (=ventral) pair smaller and shorter than upper (=dorsal) pair of lobes (Fig. 1). Anterior projection of dorsal pair of branchial lobes (fifth lobe) not present. A large pointed projection of posterior region of lower lobes (=posterior filament) present (although deciduous and sometimes damaged), of about $1 / 2$ of length of lower lobe (Figs. 1d and 5b). Dorsal lobes without this terminal projection (Figs. 1d, 5b, c and 7b). Loss of branchial lobes rare, only observed in paratype NMS.Z 2015.023.5 affecting the left dorsal lobe (Fig. 2a). Both sides of branchial lamellae provided with parallel bent rows of cilia (Fig. 5d), but poorly defined in smaller specimens (Fig. 2a, b). Well-developed branchiae (e.g. paratype NMS.Z 2015.023.5) with a tuft of cilia at edge of each branchial lamella in interbranchial zone of dorsal lobes; wide ciliated band in inferior part of supporting branches of all four branchial lobes also present (Fig. 5b, c); other tufts of cilia or marginal papillae on outer edge of lamellae not observed (Figs. 2a, b and $5 \mathrm{~b}, \mathrm{c}, \mathrm{d})$. Micro-CT transversal plane at branchial level showing two well-defined cavities inside branchial stem separated by a septum (Fig. 8c).

Eighteen thoracic chaetigers (SGIII-XX), all provided with notopodia and also with neuropodia from SGVIII. All notopodia of similar size; notopodia of TC1 and TC2 slightly displaced dorsally (Fig. 2c, d). All notochaetae long simple capillaries of similar length. Thoracic neuropodia present as 
sessile pinnules from TC6 (SGVIII) to TC18 and provided with uncini in single rows starting from TC7 (SGIX) throughout. First thoracic neuropodia (TC6) provided with geniculate acicular hooks. Thoracic notochaetae arranged in two rows (Fig. 3a) and with textured surface (Fig. 3b, c, d). Geniculate chaetae sharply bent (Fig. 3e) ranging from 6 to 9 in number, provided with minute teeth forming a capitium (Fig. 6b, c) and showing internal structure formed by fused hollow channels (Fig. 3f). Subsequent thoracic neuropodia with about 8-10 uncini per torus. Uncini as shafted denticulate hooks provided with long, thin and pointed rostrum surmounted by 4 teeth and an upper crest of several smaller denticles of different sizes (Figs. 4a, b and 6d). One papilla dorsal to each thoracic notopodia (Figs. 2d and 5e), each composed by row of holes (Fig. 2e, f) sometimes with cilia protruding from inside (Figs. $5 \mathrm{f}$ and 6a). Nephridial openings button hole-shaped, dorsal to notopodia and ventral to thoracic dorsal papilla in TC4 and TC5 and maybe in TC1 (Fig. 2c).

Fig. 3 Terebellides shetlandica spec. nov. (NMS.Z 2015.023.5) (a) detail of TC7 to TC9 notopodia; (b) anterior thoracic notochaeta; (c) detail of thoracic notochaetae covering, proximal part; (d) detail of thoracic notochaetae covering, distal part; (e) geniculate chaeta of TC6; (e) broken TC6 geniculate chaetae showing inner channels
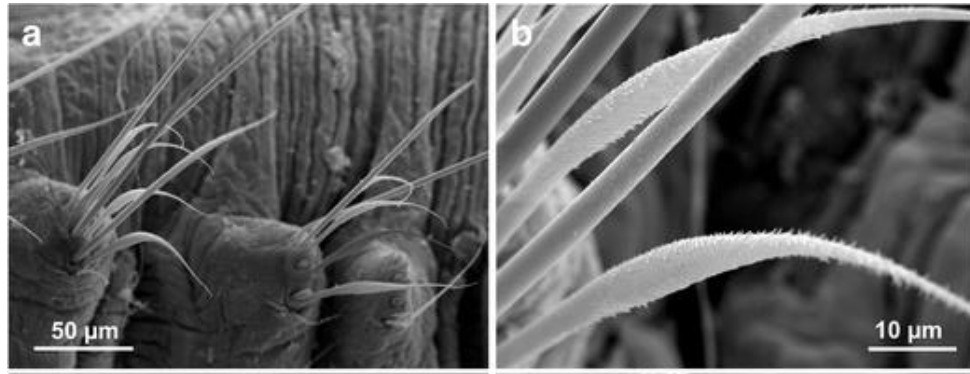

c
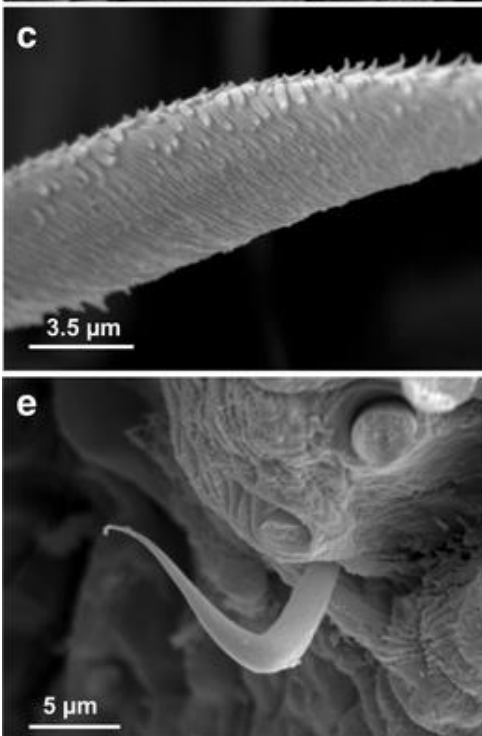

d
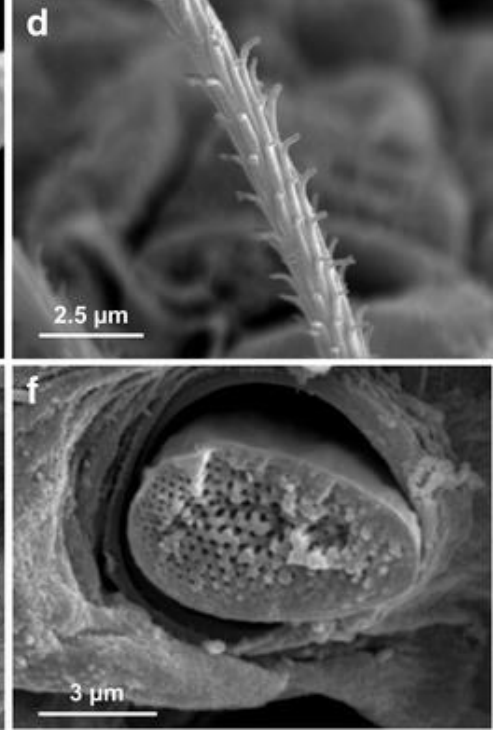
Fig. 4 Terebellides shetlandica spec. nov. (NMS.Z 2015.023.5) (a) uncini of thoracic unciniger; (b) three thoracic uncini in upper-lateral view; (c) anterior abdominal unciniger; (d) midabdominal unciniger; (e) abdominal uncini in upper view; (f) abdominal uncini in frontal view; number of teeth over rostrum circled. Abbreviations: adp=abdominal dorsal papilla

Fig. 5 Terebellides shetlandica spec. nov. (NMS.Z 2015.023.5) (a) anterior end, lateral view of a 4-lobed branchiae specimen with an attached copepod in left body side; (b) detail of the branchial lobes, arrows showing long pointed projections of ventral lobes ("terminal filament"); (c) detail of branchial lobes posterior end showing ciliation pattern, arrow showing long pointed projection of right ventral lobe; (d) detail of ciliation of inner faces of branchial lamellae; (e) postero-lateral view of TC2 to TC6; (f) detail of ciliated area of a thoracic dorsal papilla. Abbreviations: $a b c=a b f r o n t a l$ cilia; $b a c=b r a n c h i a l$ axis cilia; lmc=lamellar cilia; ldl=left dorsal lobe; lvl=left ventral lobe; $p c=$ parasitic copepod; rdl=right dorsal lobe; rvl=right ventral lobe; $\mathrm{TC}=$ thoracic chaetiger; tdp=thoracic dorsal papilla
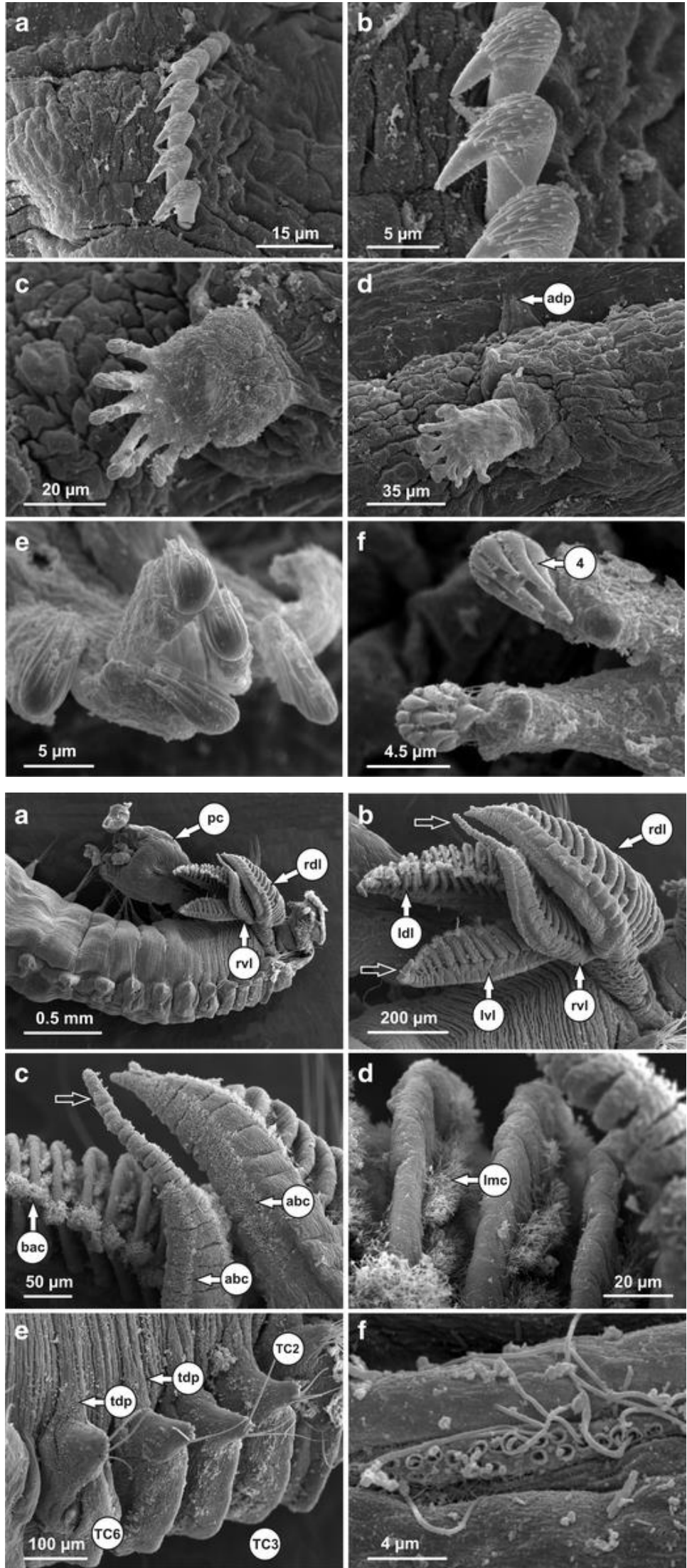
Fig. 6 Terebellides shetlandica spec. nov. (NMS.Z 2015.023.5) (a) detail of ciliary openings of an abdominal dorsal papilla; (b) two geniculate chaetae of TC6 (arrow marking position of teeth of capitium); (c) detail of teeth of capitium of a geniculate chaeta; (d) three thoracic uncini; number of teeth over rostrum circled; (e) detail of aberrant thoracic uncini showing malformations affecting both to rostral (1) and capital teeth (2); (f) abdominal uncini in upper view; number of teeth over rostrum circled
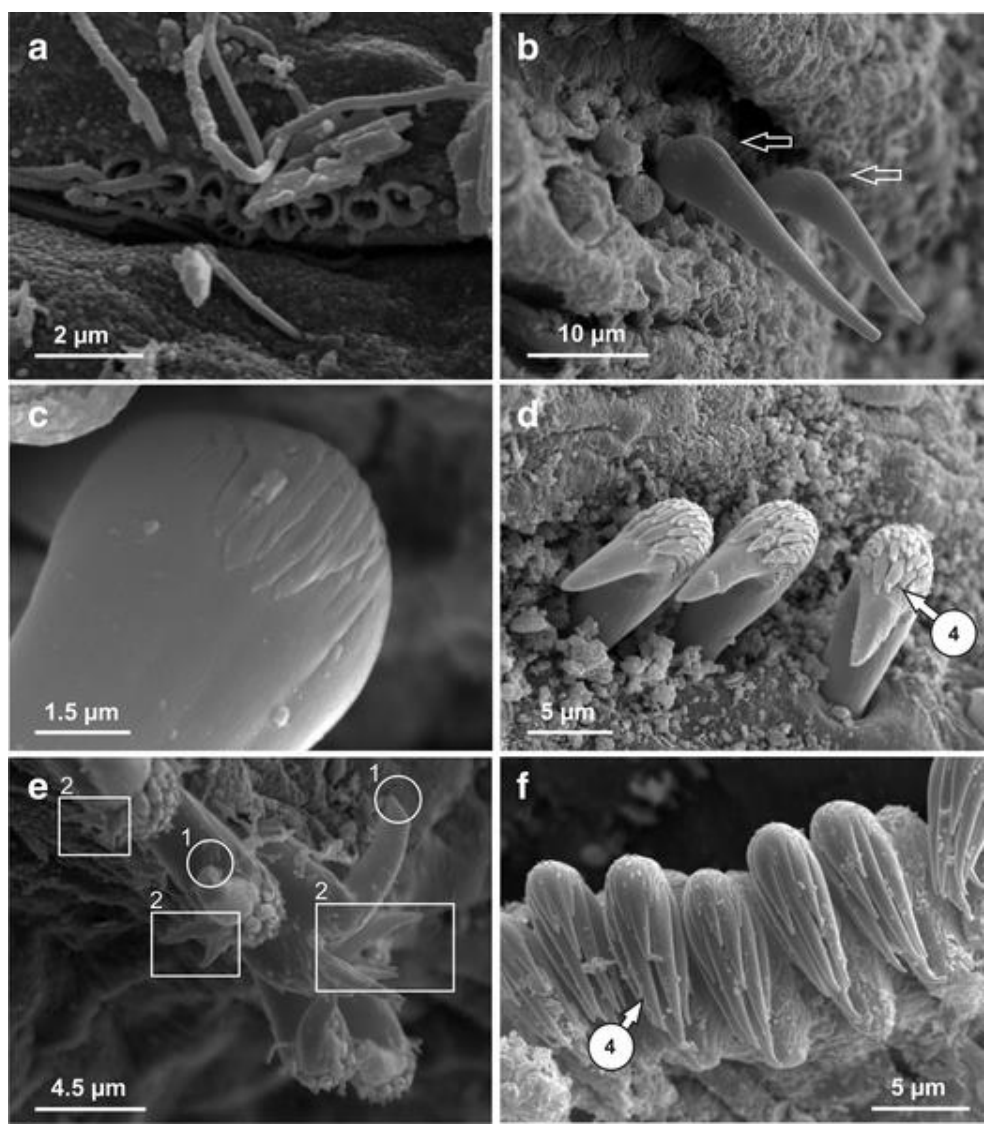

Number of abdominal chaetigers ranging from 20 to 28 in smaller individuals $(6-10 \mathrm{~mm}$ in length) and up to 30 chaetigers in larger specimens ( $8-19 \mathrm{~mm}$ in length) plus holotype. Abdominal neuropodia as erect pinnules provided with about 6-12 uncini per torus (Fig. 4c, d). Uncini with 3-4 teeth above main fang (Figs. 4e, f and 6f), surmounted by a row provided with an irregular number of shorter teeth and an upper crest of minute teeth. Several deformities observed in one SEM specimen in uncini of last thoracic chaetiger, affecting both rostrum and capitium teeth (Fig. 6e). One papilla similar to thoracic ones observed dorsally to each abdominal neuropodia (Fig. 4d).

Pygidium blunt, funnel-like depression. Colour in alcohol pale brown.

Holotype with oocytes in body cavity.

Methyl green staining pattern 1 resulting in a compact green colouration in $\mathrm{CH} 1-6$, then turning into striped pattern in $\mathrm{CH} 7-12$ and fading in following segments.

Scar from parasitic copepod dorsally to notopodia of left side of TC3 of holotype (Fig. 7b). 
Fig. 7 Terebellides shetlandica spec. nov. (holotype NMS.Z 2013.07.01) 3D micro-CT reconstruction of external morphology: (a) latero-frontal view of right thoracic region; (b) latero-ventral view of left thoracic region.

Abbreviations: cas $=$ copepod attachment scar; dl=dorsal lobe; gc=geniculate chaetae; lat=lateral lappets; $\mathrm{pf}=$ =posterior filament; $\mathrm{SG}=$ segment; $\mathrm{TC}=$ thoracic chaetiger; $\mathrm{tm}=$ tentacular membrane; $\mathrm{vl}=$ ventral lobe
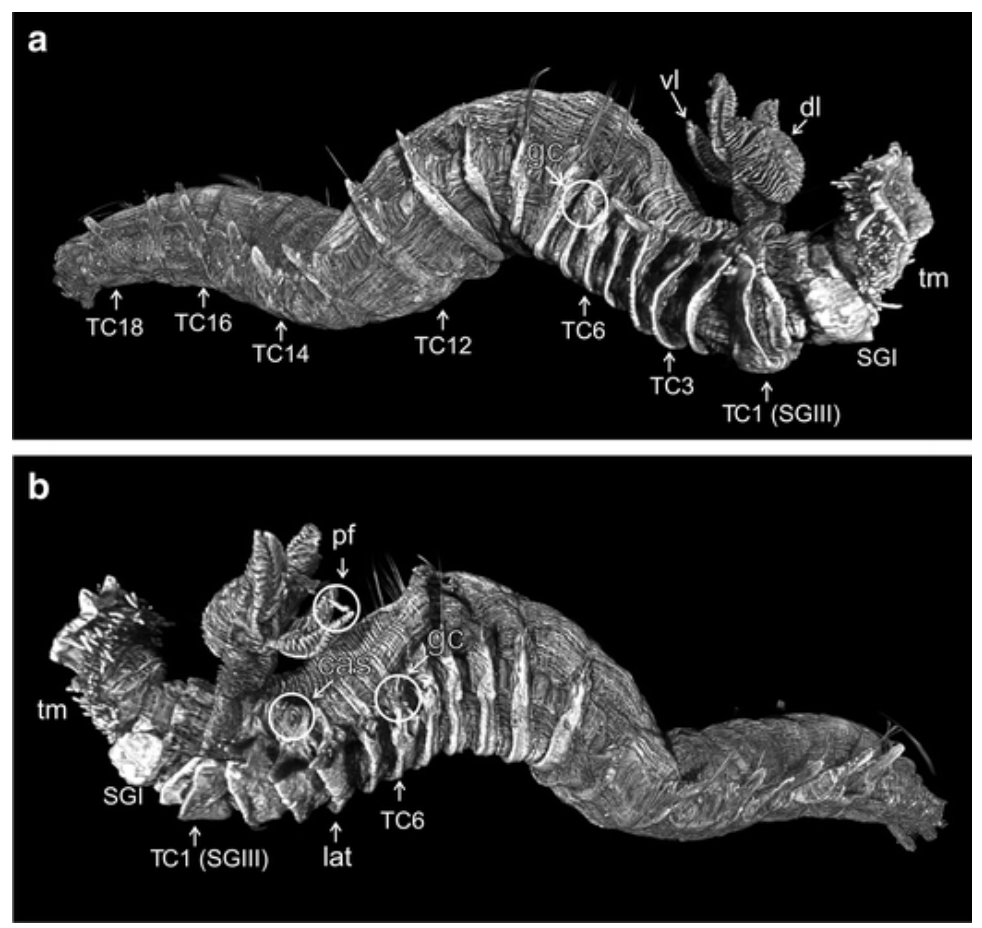

Gross internal morphology of holotype. - The internal morphology of the holotype was also studied using the micro-CT (Figs. 7 and 8). The 3D images (Fig. 7) show two main diagnostic characters, i.e. the branchial structure and well-developed lateral lappets from TC1 to TC6, but also geniculate chaetae in TC6 and the scar marking the attachment point of a parasitic copepod eventually detached. Sagittal and frontal plane images show the typical Terebellides highly-regionalized anterior part of the digestive tract, occupying most of the thoracic region of the body, with four well defined areas (Fig. 8a, b). These correspond to the oesophagus, the anterior region of the stomach (=fore stomach), the posterior region of the stomach (=hind stomach), and the beginning of the large intestine (=fore intestine,), which runs through the posterior half of the body with almost no detectable anatomical specialization before reaching the pygidium. The transversal section at the $\mathrm{OE}$ level, situated at about TC1 in this specimen, shows the ventral pharyngeal pouch provided with a thick bilobed muscle bulb (Fig. 8c). The FS is located at the level of ca. TC12, is characterised by a small lumen (Fig. 8d), is provided by a thin stomach wall and is covered by a voluminous and multi-layered digestive gland (Fig. 8d). The HS, located in the holotype at ca. TC14, is of similar length as FS, but is characterised by a large lumen, the absence of the digestive gland and a much thicker muscular stomach wall (Fig. 8e). The beginning of the fore intestine (FI) can be noticed by the sudden change in the thickness of the digestive wall (star in Fig. 8b; compare Fig. 8e and f). The complete digestive system lumen is filled with electro-dense sand remains, especially in FS and HS. 

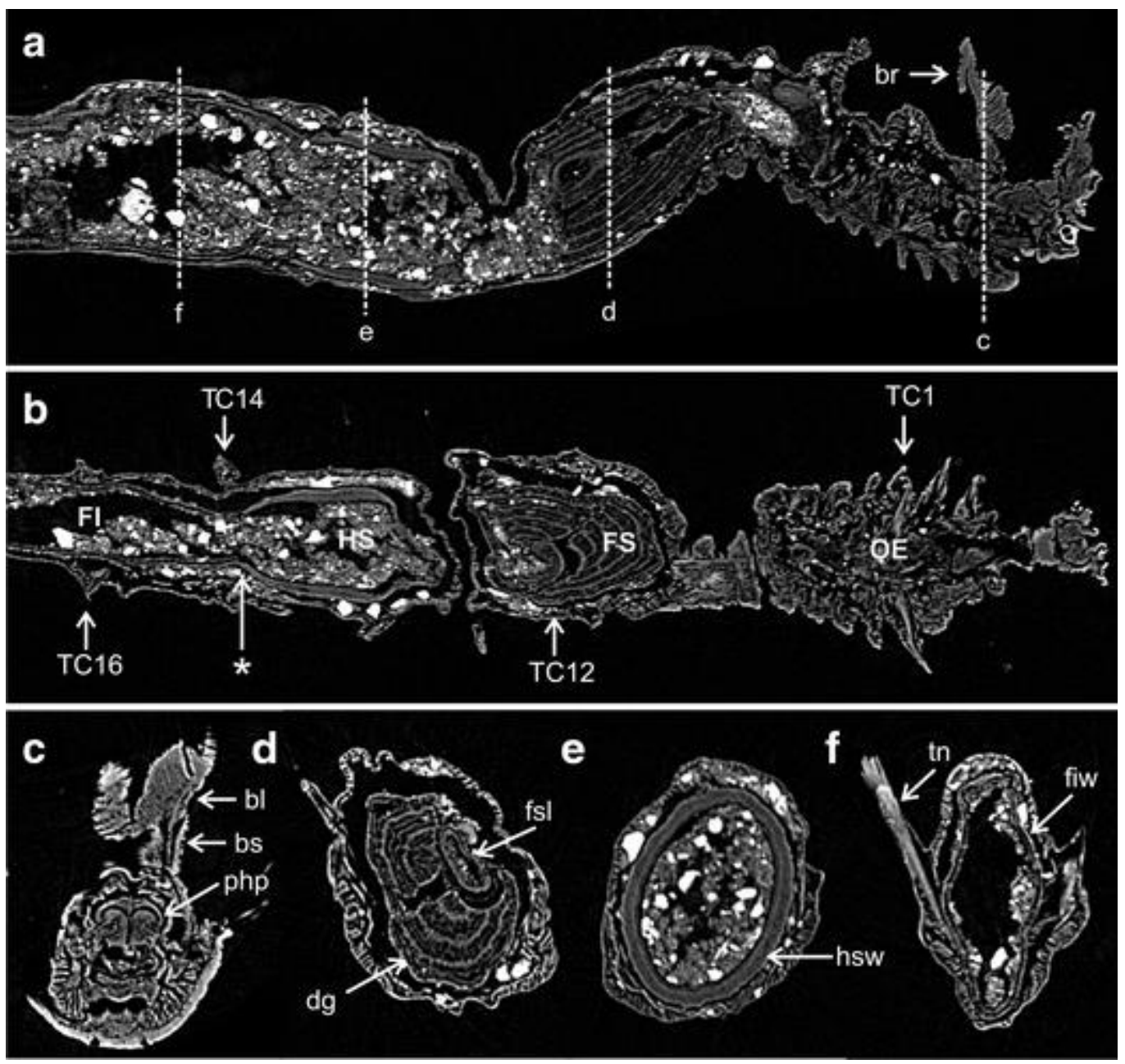

Fig. 8 Terebellides shetlandica spec. nov. (holotype NMS.Z 2013.07.01) Micro-CT images of internal anatomy: (a) sagital plane showing internal body organization; dotted lines marking position of transversal sections showed in figures c, e and f; (b) frontal plane of same showing regionalization of anterior digestive; star showing the point of onset of the intestine; (c) transversal section at level of oesophagus showing the ventral pharyngeal pouch; (d) transversal section at level of fore stomach showing the digestive gland; (e) transversal section at level of posterior stomach showing its thick muscle layer; (f) transversal section at level of fore intestine showing its thin wall. Abbreviations: bl=branchial lobe; bs=branchial stem; FI=fore intestine; fiw=fore intestine wall; FS=fore stomach; fsl=fore stomach lumen; HS=hind stomach; hsw=hind stomach wall; OE=oesophagus; php=pharyngeal pouch; $\mathrm{TC}=$ thoracic chaetiger; $\mathrm{tn}=$ thoracic notopodia

Remarks. - Among the five species of Terebellides described or reported in north-east Atlantic waters (see key), the most similar species to T. shetlandica spec. nov. is T. atlantis sensu Parapar et al. (2011). Both species are small sized (T. atlantis: 8-18 mm in length vs. T. shetlantica spec. nov.: 6$15 \mathrm{~mm}$ in length) and have four branchial lobes free from each other. Nevertheless, branchial lobes of T. atlantis sensu Parapar et al. (2011) are noticeably different to the ones of $T$. shetlandica spec. nov., having in T. atlantis sensu Parapar et al. (2011) all lobes similar in shape and length, and highly deciduous, lacking several lobes in many of the studied specimens. On the contrary, in T. shetlandica spec. nov. the lobes differ in shape and size and only one specimen have lost one branchial lobe. Furthermore, T. shetlandica spec. nov. may be easily distinguished by the presence of a posterior filament in each of the lower branchial lobes. Other differences rely on the dorsal most position of the 
notopodia of TC1 and TC2 in T. shetlandica spec. nov. and the smaller number of uncini in abdominal uncinigers (ca. 25 uncini per torus in T. atlantis vs. 6-7 in T. shetlandica spec. nov.).

Five Terebellides species have been described in north-west Atlantic waters: Terebellides lobatus Hartman and Fauchald 1971, Terebellides distincta Williams 1984, Terebellides carmenensis Solís-Weiss et al. 1991, Terebellides lanai Solís-Weiss et al. 1991 and Terebellides parvus SolísWeiss et al. 1991. Terebellides lobatus (deep equatorial waters) is an ill-defined species characterised by branchiae provided with four non-fused lobes and gently bent geniculate chaetae in CH6 (Hartman and Fauchald 1971; p. 175, Fig. 19); T. distincta (New England slope) differs from the other described species in the presence of a pointed internal structure in the acicular chaetae (Williams 1984; p. 124, Fig. 5); T. carmenensis (off Mexico) is characterised by a conspicuous dorsal hump in CH7 (SolísWeiss et al. 1991; p. 151, Fig. 1j); T. lanai (off Brazil) is distinguished by having branchial lobes fused along most of their length, and T. parvus (shallow waters in Belize) is characterised by the low number (20 to 26) of abdominal chaetigers. Terebellides anguicomus Müller 1858 and Terebellides klemani Kinberg 1867, both originally described from the south-west Atlantic, were also reported by Solís-Weiss et al. (1991) for Belize and the Mexican Caribbean. T. anguicomus is characterised by having only 17 thoracic chaetigers and geniculate chaetae in $\mathrm{CH} 5$ instead of $\mathrm{CH} 6$, and T. klemani is characterised by a 5-lobed branchiae with lobes free almost to the base of the stalk, and gently bent geniculate chaetae in CH6 (Solís-Weiss et al. 1991). Anyway, T. shetlantica spec. nov. may be distinguished by the length of the projection of the ventral branchial lobes, which is indeed much longer than in all other species of the NE Atlantic and in all remaining species of the genus, where it is always short (Solís-Weiss et al. 1991).

Infestation by ectoparasitic copepods. - Seven of the studied specimens (50\%) were parasitized by either one or two individuals of the copepod Melinnacheres terebellidis (Levinsen 1878) (Figs. 1 and 5a). Five Terebellides specimens carry only one copepod, three on the left side of TC3 and two on the right side; two specimens carry two copepods, one on each side of TC3. Most of the specimens are females with egg sacs. Infected individuals show no apparent deformity associated with parasitization. Parasitization seems to be independent of host body size. Traces of previous parasite presence (attachment scar) were also detected on the holotype (Fig. 7b).

Distribution and habitat. - Specimens of T. shetlandica spec. nov. were found in offshore stations east of the Shetland Islands in the northern North Sea and also near the Western Isles, Scotland and off the SW coast of England; 100-160 m water depth. Depth data known only from holotype and three paratypes; no data available about bottom type and abiotic features.

Etymology. - The name of the species refers to the Shetland Islands, where most of the specimens were collected. 


\section{Discussion}

Internal anatomy. - The micro-CT images obtained from the holotype of $T$. shetlandica spec. nov. show the same pattern of digestive regionalization previously observed by Michel et al. (1984) in Mediterranean specimens of T. stroemii, by Williams (1984) in Norwegian specimens of T. stroemii and north-west Atlantic T. distincta, by Penry and Jumars (1990) in NW Atlantic T. stroemii, and recently by Parapar and Hutchings (2015) in their description of the neotype of this species. In $T$. shetlandica spec. nov. and the aforementioned specimens of $T$. stroemii the two stomach regions (FS and HS) are similar in size (see Williams 1984, Fig. 6a and Parapar and Hutchings 2015, Fig. 10a). Parapar and Hutchings (2015) noted in T. stroemii the large capacity of the anterior region of the digestive system shifts along the longitudinal body axis when comparing the neotype and a neoparatype. Thus, the FS appears at the level of the branchiae (ca. TC4) in the micro-CT images of the neotype, while in the dissected neoparatype they appear further back (TC7-10) (Parapar and Hutchings 2015). In T. shetlandica spec. nov. both regions of the stomach are located even further back (FS in TC12 and HS in TC14 approx.); this is probably due to the slight dorso-ventral flattening of the specimen after the branchial region and has not been therefore considered as being a relevant interspecific difference.

Morphology of the branchiae. - The genus Terebellides is characterised by the peculiar features of the branchiae, which are anteriorly located, lobed and lamellated. There is no consensus about whether branchiae are located in SG2, 3 or 4 (Fauvel 1927; Day 1967; Fauchald 1977); recent works, however, suggest either SG3 (TC1) (e.g. Holthe 1986; Garraffoni and Lana 2003, 2004) or SG3-4(TC1-2) (e.g. Hutchings and Peart 2000). Similarly, there is no agreement about how many pairs of simple branchiae gave rise to the branchiae present in extant Terebellides; anyway, it has been usually considered that branchiae are comprised by four lobes originating from two pairs of branchiae. However, Jouin-Toulmond and Hourdez (2006) found that the branchial stem has two pairs of coelomic cavities containing blood vessels that corresponds to SGIII-IV plus a fifth one located medially possibly corresponding to SGII, but reduced and with no blood vessel. Thus, although these authors illustrate two pairs of branchiae (see Fig. 5b), they suggest that the presence of this reduced median cavity in the branchial stalk (see Fig. 3a) may represent a residual extension of the coelomic cavity of SG2; this may, in turn, indicate that this organ may be derived from an hypothetical ancestor with three, and not two, pairs of lateral branchiae (Jouin-Toulmond and Hourdez 2006). This point of view has been explicitly rejected by Muir (2011).

The true diversity of the genus has remained hidden for a long time, with very few described species; in fact, the type species (i.e. T. stroemii) has been supposed as having a cosmopolitan distribution, as it has happened with many marine invertebrates. However, since the early 1980s, the overall picture has changed substantially because researchers have begun to pay much more attention 
not only to the branchiae but to the morphological diversity of external body characters. In this context, it now seems appropriate to provide a standardization for the description of branchial characters, as well as trying to establish the various basic body models that could help to reveal potential phylogenetic relationships in the future.

Thus, we suggest that any description of the Terebellides branchiae should take into account the following characters (Figs. 9 and 10):
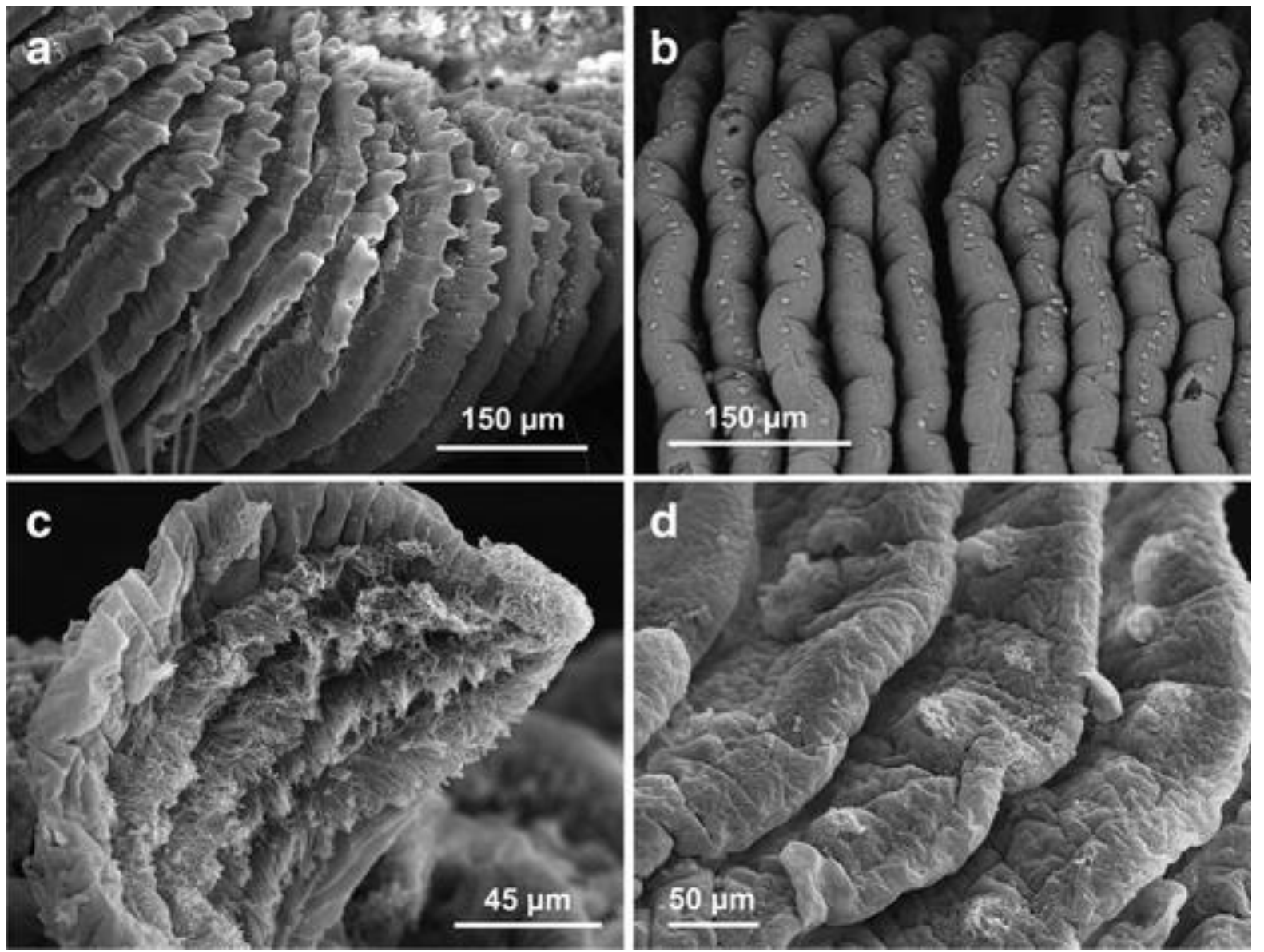

Fig. 9 Branchial characters in the genus Terebellides: (a) SEM micrograph of outer edge of several branchial lamellae in T. stroemii from the Adriatic Sea (specimen PMR-14571 in Parapar et al. 2013) showing marginal papillae; (b) SEM micrograph of outer edge of several branchial lamellae in T. longicaudatus from Antarctica (specimen SMNH 6625 in Parapar and Moreira 2008) showing marginal ciliary tufts; (c) SEM micrograph of inner face of a branchial lamella of T. mediterranea (specimen PMR14559 in Parapar et al. 2013) showing lamellar ciliary rows; (d) SEM micrograph of inner face of a branchial lamella in T. gracilis from Iceland (specimen IINH 24931 in Parapar et al. 2011) showing lamellar ciliary tufts 

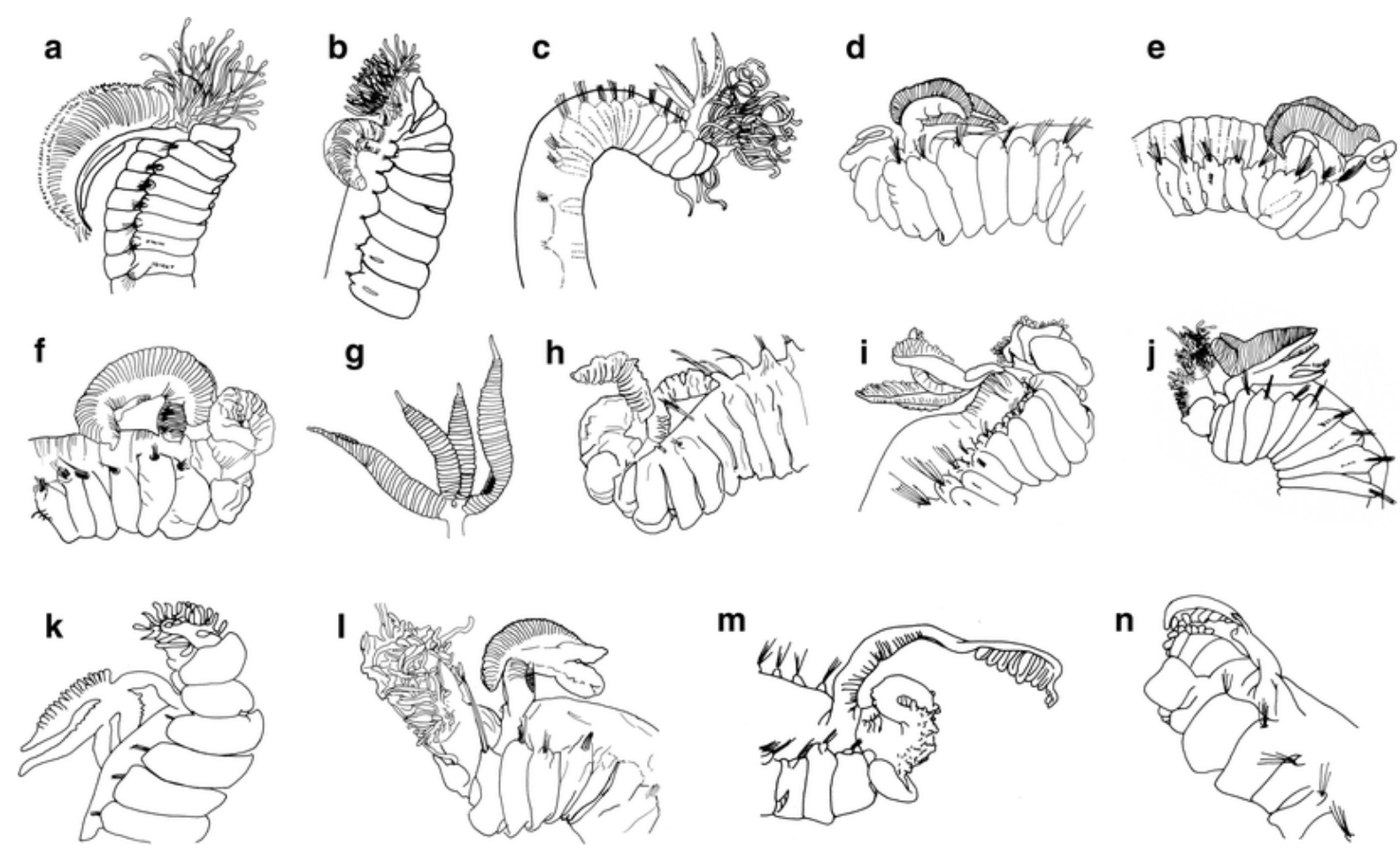

Fig. 10 Several examples of branchial morphologies in the genus Terebellides; all redrawn from original line drawings or SEM micrographs: (a) T. stroemii Sars 1835 (sensu Berkeley and Berkeley 1952, Fig. 152); (b) T. stroemii Sars 1835 (sensu Uschakov 1955, Fig. 142A); (c) T. ehlersi McIntosh 1885 (original, McIntosh 1885, Fig. 51-8); (d) T. intoshi Caullery 1915 (sensu Imajima and Williams 1985; Fig. 2a); (e) T. kobei Hessle, 1917 (sensu Imajima and Williams 1985; Fig. 3a); (f) T. longicaudatus Hessle 1917 (sensu Parapar and Moreira 2008, Fig. 4a) (g) T. lobatus Hartman and Fauchald 1971 (original, Hartman and Fauchald 1971, Fig. 30b); (h) T. atlantis Williams 1984 (sensu Parapar et al. 2011, Fig. 2a); (i) T. mundora Hutchings and Peart 2000 (original, Hutchings and Peart 2000, Fig. 14a); (j) T. parvus Solís-Weiss et al. 1991 (original, Solís-Weiss et al. 1991, Fig. 2a); (k) T. sepultura Garraffoni and Lana 2003 (original, Garraffoni and Lana 2003; Fig. 1); (1) T. mediterranea Parapar et al. 2013 (original, Parapar et al. 2013, Fig. 5a); (m) T. mira Schüller and Hutchings 2013 (original, Schüller and Hutchings 2013, Fig. 9a); (n) T. rigel Schüller and Hutchings 2013 (original, Schüller and Hutchings 2013, Fig. 12)

1. Length of branchial stem. The stem is usually much shorter than the branchial lobes (e.g. T. longicaudatus Hessle 1917 sensu Parapar and Moreira 2008; Fig. 10f) but sometimes may be much longer, as it happens in some deep-sea species (e.g. T. mira Schüller and Hutchings 2013; Fig. $10 \mathrm{~m}$ ). Some recent descriptions of Terebellides species also include the annulation of the stem as a diagnostic character (e.g. T. ginkgo Schüller and Hutchings 2012); we do not deny the validity of this character but it should be taken into account that apparent annulation might be due to shrinkage during collection and/or preservation of the specimens.

2. Total length of branchiae. It is estimated as the thoracic chaetiger reached by the rear end of the longest pair of lobes, usually the upper ones. A review of the literature reveals total length can vary substantially depending on the species (e.g. T. stroemii Sars 1835sensu Berkeley and Berkeley 1952, Fig. 10a and sensu Uschakov 1955, fig. 10b). Similarly, different names have been given to the branchial lobes in the literature; we believe that 
terms as upper/lower and left/right may be more appropriate than others like $\mathrm{i}$ to iv (Hutchings and Peart 2000), 1 to 4 or well-developed/reduced (e.g. Jouin-Toulmond and Hourdez 2006), superior/inferior (Solís-Weiss et al. 1991; Parapar and Moreira 2008); dorsal/ventral (Gagaev 2009) or anterior/posterior (Schüller and Hutchings 2010, 2012).

3. Presence and length of a "fifth lobe". We follow here Garraffoni and Lana (2004) in preferring to code this character as absence or presence of and "anterior projection" rather than a "fifth lobe", as most recent authors do. If we consider, as Muir (2011) does, that Terebellides has probably evolved from a form with four lateral branchiae, one might expect that the plesiomorphic state in the genus is having four branchial lobes, which later might have evolved to an apomorphic state defined by the presence of a lesser number of lobes.

4. Number of branchial lamellae. The number and degree of packing of branchial lamellae on lobes should also be described as accurately as possible. This character seems to be closely related to the size and shape of the branchiae. Thus, in comma-shaped branchiae with fused lobes (see below) their number is usually much higher and more tightly packed than in branchiae with unfused lobes.

5. Presence of papillar projections. These projections are located in the marginal edge of the lamellae of the upper branchial lobes and have been recorded in several species from the Gulf of Mexico (Solís-Weiss et al. 1991) and recently by Parapar et al. (2013, Fig. 9a) in the Adriatic Sea.

6. Branchial ciliation. This character has been poorly studied, probably because it can only be properly appreciated by SEM examination. The branchiae constitute an organ profusely ciliated in Terebellides, probably to allow effective gas exchange. There are ciliated rows always present on both sides of the branchial lamellae, mostly arranged as concentric lines (T. stroemii sensu Parapar et al. 2013, Fig. 9c), which in some cases have been reported as ciliated tufts in its peripheral area (T. gracilis Malm 1874 sensu Parapar et al. 2011, Fig. 9d). Apart from those, some cilia were also detected along the edge of the lamellae in some species (T. longicaudatus Hessle 1917 in Parapar and Moreira 2008, Fig. 9b). In this paper, we reported for the first time a ciliary band located along the stem supporting the four lobes (Fig. 5b, c), which does not extend along the filamentous tips.

7. Filamentous tips. Many Terebellides species were described with filamentous tips on the rear end of both upper and lower lobes (e.g. T. lobatus Hartman and Fauchald 1971, Fig. $10 \mathrm{~g}$ ). Its relevance as a taxonomic character was not clear because of their usual small size and deciduous nature after a rough sampling and the preservation processes. However, the presence of longer filaments in the lower lobe as it happens in $T$. shetlandica spec. nov. (Fig. 1d) may constitute a useful character. 
8. Shape of lower lobes and degree of fusion. This character, which is definitely one of the most important in the characterization of the Terebellides branchiae, is perhaps the most poorly observed in detail so far; this is probably due to the preeminence of the upper lobes, usually much developed, and which may hide the lower ones. Lower lobes usually are subequal in size the with upper ones (T. lineata Imajima and Williams 1985) or clearly shorter (T. horikoshi Imajima and Williams 1985), but may also be much smaller (T. rigel Schüller and Hutchings 2013) and even absent (T. mira Schüller and Hutchings 2013); absence might also be due to the lobes being highly deciduous ( $T$. mundora Hutchings and Peart 2000). The most usual situation is that lower lobes are visible beneath the upper lobes; in that case it is relevant to assess the relative size of upperlower lobes and the degree of fusion among them.

9. Glandular area on lower lobes. Jouin-Toulmond and Hourdez (2006) recorded the presence of a glandular area covered with tufts of cilia in the ventral surface of the lower branchial lobes. This character was never mentioned in any hitherto described Terebellides species, and has not described since.

Putting together all these characters, and with the purpose of providing an initial approach to a better characterization of the branchiae in Terebellides, we propose four basic models of branchial structure.

- Type 1. Branchial lobes almost completely fused, typically comma-shaped, with the widest part located anteriorly. Only upper lobes can be clearly seen, lower lobes being partially or totally obscured. Different sizes of this type were described; for instance, large ones reach TC6 with a maximum length reaching almost same value as maximum thoracic length (e.g. T. stroemii sensu Berkeley and Berkeley 1952; Fig. 8a); lobes are, however, usually more slender and reaching TC3-4 (e.g. T. kobei Hessle 1917 sensu Imajima and Williams 1985, Fig. 8e, and T. longicaudatus Hessle 1917 sensu Parapar and Moreira 2008, Fig. 8f). An extreme case of the latter is shown by T. stroemii Sars 1835sensu Uschakov (1955) (Fig. 8b) which shows an extremely small branchia. Type 1 also usually bears a high number of tightly packed lamellae in upper lobes, short posterior elongation of the lobes (the "branchial filament") and upper lobes are usually anteriorly elongated forming the so-called fifth lobe. Species with this type of branchiae were reported at very different depths (Fig. 11). 


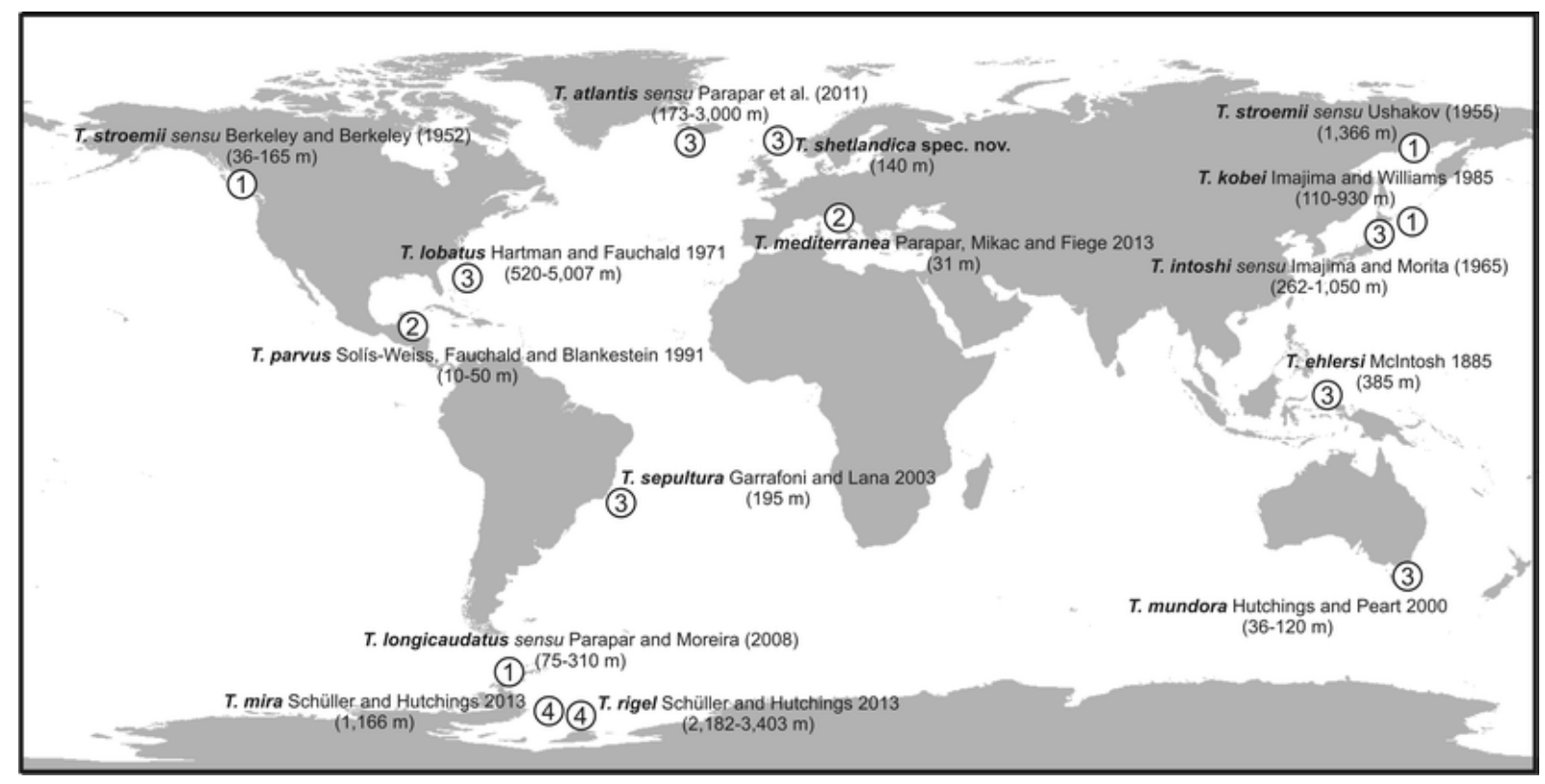

Fig. 11 World map showing several examples of Terebellides species having the different types of branchiae described in the text (encircled)s

- Type 2. Upper lobes fused about $50 \%$ of their length and with a similar shape to upper lobes of type 1, but with lower lobes easily seen from the ventral part, being much smaller than upper ones and emerging after the fusion area with those. This type usually bears also a high number of tightly packed lamellae in upper lobes, while lower lobes are much less developed, with short posterior filaments and large anterior prolongation of dorsal lobes. Typical examples of this branchial type are T. parvus Solís-Weiss et al. (2001) (Figs. 8j and 11) and T. mediterranea Parapar et al. (2013) (Figs. 81 and 11), which are shallowwater species.

- Type 3. All branchial lobes are more or less similar in size (although lower lobes may be a bit shorter), non comma-shaped, and fused only basally. This is very widespread type of branchiae among species of Terebellides all over the world oceans (Fig. 11) (e.g. T. intoshi Caullery 1915 sensu Imajima and Williams (1985); T. ehlersi McIntosh 1885, Fig. 8d; T. lobatus Hartman and Fauchald 1971, Fig. 8 g; T. sepultura Garraffoni and Lana 2003, Fig. 8 k). The low degree of fusion of the branchial lobes is probably the reason why some specimens of certain species with this branchial type may lose some of the lobes probably due to damage during sampling (e.g. T. atlantis Williams 1984sensu Parapar et al. 2011, Fig. 8 h; T. mundora Hutchings and Peart 2000, Fig. 8i). Furthermore, the stalk is usually long, there are both high or low number of lamellae in lobes (loosely packed in the last case), there is no fifth lobe and a short posterior filament may be present. 
- Type 4. Branchiae with very long stem (longer than lobes), lobes free from each other and provided with a few broad and loosely packed lamellae (e.g. T. mira Schüller and Hutchings 2013, Fig. 8 m) (Fig. 11). Ventral lobes are distinctly smaller than dorsal ones (specially in T. rigel Schüller and Hutchings 2013, Fig. 8n) and fifth lobe is absent.

Copepod infestation. - Among the many parasitic copepods, little is known about those infesting polychaete worms. Around 30 species of polychaete-associated copepods were cited by O'Reilly (1991) from waters around the British Isles. These are included the synopsis by Gotto (1993) of copepods associated with invertebrates but since then several new records and new species from polychaetes have been found in British waters (O'Reilly 1995a, b, 1999, 2000; O' Reilly and Geddes 2000; O'Reilly et al. 2011) and also in nearby European waters (Kim et al. 2013). The polychaete taxa more often infected by parasitic copepods include the families Ampharetidae, Maldanidae, Polynoidae, Sabellidae, Spionidae, Terebellidae and Trichobranchidae but many other polychaete families may also harbour such parasites either internally or externally (see Boxshall and Halsey 2004).

The copepod species found parasitizing T. shetlandica spec. nov. is Melinnacheres terebellidis (Levinsen 1878). Levinsen (1878) described the species as Saccopsis terebellidis Levinsen 1878 from West Greenland, parasitizing Terebellides stroemii. A similar species, described as Saccopsis steenstrupi by Bresciani and Lützen (1961) also parasitises Terebellides stroemii in NE Atlantic waters. Bresciani and Lützen (1975) found that Saccopsis should be considered as junior synonym of Melinnacheres and consequently be abandoned. The genus Melinnacheres comprises only four species, namely M. ergasiloides Sars 1870 from Melinna cristata (Sars 1870) in the North Atlantic, M. levinseni (McIntosh 1885) from Ehlersiella atlantica McIntosh 1885 in the mid-Atlantic, and the afore-mentioned M. terebellidis and M. steenstrupi both from T. stroemii. Melinnacheres are highly transformed ecto-parasitic copepods. The females are sac-like and devoid of any obvious appendages apart from a pair of egg strings when mature. Vestigial antennae and mouthparts are present but difficult to discern even under high magnification. The male copepods also exhibit reduced morphology and are minute dwarfs attached to the female genital area. The female $M$. terebellidis has an oblong body shape up to $4 \mathrm{~mm}$ long, tapering anteriorly and always attaches to the anterior dorsum of its host. The female M. steenstrupi has an ovoid body shape up to $1.8 \mathrm{~mm}$ long and always attaches to the branchiae of its host. M. steenstrupi is already known from British waters but $M$. terebellidis is known only from Greenland and Iceland. The designation of the original host of M. terebellidis as $T$. stroemii must remain uncertain as additional Terebellides species have since been recognized as occurring in the area (Parapar et al. 2011). 
Key to north-east Atlantic and Mediterranean Terebellides species. - The following key includes all Terebellides species originally described or reported in North-east Atlantic and Mediterranean waters (type locality in brackets).

1 Geniculate acicular chaetae on TC6 2

- Geniculate acicular chaetae on TC5 and TC6 T. bigeniculatus [NW Iceland]

2 Thoracic $\mathrm{CH} 1$ to $\mathrm{CH} 4$ ventrally whitish T. gracilis $^{1}$ [Spitsbergen]

- Thoracic $\mathrm{CH} 1$ to $\mathrm{CH} 4$ showing same ventral colouration as following... 3

$3 \mathrm{CH} 1$ notopodia and notochaetae longer than following T. mediterranea [Adriatic Sea]

- $\mathrm{CH} 1$ notopodia and notochaetae similar or shorter than following 4

4 Branchial lobes moderately fused; large species (up to $50 \mathrm{~mm}$ long) T. stroemii ${ }^{2}[$ Bergen]

- Branchial lobes free; smaller species (less than $20 \mathrm{~mm}$ long) 5

5 Pair of lower (ventral) branchial lobes with short pointed projection; upper lobes similar in size and shape to lower ones T. atlantis ${ }^{3}$ [New England slope, western North Atlantic]

- Pair of lower (ventral) branchial lobes with long pointed projection of about $1 / 3$ of lobe total length, upper lobes different in size and shape to lower ones .T. shetlandicaspec. nov. [Shetland Islands]

(1) This species was traditionally considered synonym of T. stroemii (Hartman 1959; Holthe 1986), but Hansson (1998), followed by Parapar et al. (2011), regards it as a valid species and senior synonym of Terebellides williamsae Jirkov 1989.

(2) Several authors suggest that under this taxon are probably hidden several species (Hutchings and Peart 2000; Parapar et al. 2011). Recently a neotype was proposed for this species (Parapar and Hutchings 2015).

(3) Original description in Williams (1984) is brief; a further description from Icelandic specimens was provided by Parapar et al. (2011), but because type material was not available for study, identification was only tentative.

\section{Acknowledgments}

We are indebted to marine ecologists who have recovered the material of $T$. shetlandica spec. nov. during the processing of benthic macrofaunal samples. These include Sue Hamilton (Edinburgh), Peter Garwood (Identichaet, Newcastle-upon-Tyne), David Hall (Unicomarine Ltd., Letchworth, Hertfordshire), and Steve Jarvis (Marine Invertebrate Ecological Services, Harpenden, Hertfordshire). 
The authors also wish to deeply thank Susan Chambers (NMS.Z) for the loan of the specimens of the new Terebellides species. Special thanks are also due to Ada Castro (SAI, UDC) for assisting with the preparation of the specimens and use of the SEM, Vituco Urgorri and María Candás (Marine Station of A Graña-Ferrol, University of Santiago de Compostela, Spain) for the micro-CT analysis, Javier Veloso (University of A Coruña, Spain) for the stereomicroscope pictures and Yolanda Lucas for the line drawings. Comments of two anonymous reviewers are also acknowledged.

\section{References}

Alba-Tercedor J, Sánchez-Tocino L (2011) The use of the SkyScan 1172 high-resolution micro- CT to elucidate if the spicules of the sea slugs (Mollusca: Nudibranchia, Opisthobranchia) have a structural or a defensive function. SkyScan Users Meeting 2011:113-121

Berkeley E, Berkeley C (1952) Canadian Pacific Fauna. 9. Annelida. 9b (2) Polychaeta Sedentaria. The University of Toronto Press for The Fisheries Research Board of Canada, Toronto, p 1-139

Boxshall GA, Halsey SH (2004) An Introduction to Copepod Diversity. The Ray Society, London

Bresciani J, Lützen J (1961) The anatomy of a parasitic copepod Saccopsis steenstrupi n. sp. Crustaceana 3(19):9-23CrossRef

Bresciani J, Lützen J (1975) Melinnacheres ergasiloides M. Sars, as parasitic copepod of the polychaete Melinna cristata, with notes on multiple infections caused by annelidicolous copepods. Ophelia 13:31-41CrossRef

Day JH (1967) A monograph on the Polychaeta of Southern Africa. Part 2. Sedentaria. Trustees of the British Museum (Natural History), LondonCrossRef

Fauchald K (1977) The Polychaete worms. Definition and keys to the Orders, Families and Genera. Natural History Museum of Los Angeles County \& The Allan Hancock Foundation. Univ South Calif Sci Ser 28:1-188

Faulwetter S, Dailianis T, Vasileiadou A, Arvanitidis C (2013) Contrast enhancing techniques for the application of micro-CT in marine biodiversity studies. Microsc Anal 27(2):S4-S7

Fauvel P (1927) Faune de France, 16. Polychètes Sédentaires. Paul Lechevalier, Paris

Gagaev SY (2009) Terebellides irinae sp. n., a new species of Terebellides (Polychaeta: Terebellidae) from the Arctic basin. Russ J Mar Biol 35:474-478CrossRef

Garraffoni ARS, Lana PC (2003) Species of Terebellides (Polychaeta, Terebellidae, Trichobranchidae) from the Brazilian coast. Iheringia Sér Zool 93:355-363CrossRef

Garraffoni ARS, Lana P (2004) Cladistic analysis of Trichobranchinae (Polychaeta; Terebellidae). J Mar Biol Ass UK 84:973-982CrossRef

Gotto RV (1993) Commensal and parasitic copepods associated with marine invertebrates (and whales). Synopses of the British Fauna (New Series), No.46. Universal Book Services, Oegstgeest, The Netherlands, p 264

Hansson HG (1998) NEAT (North East Atlantic Taxa): South Scandinavian marine Annelida Check-List, 131 pp. Available from: http://www.tmbl.gu.se Accessed January 242011 
Hartman O (1959) Catalogue of the Polychaetous Annelids of the World. Parts 1 and 2. Allan Hancock Foundation Occas Pap 23:1-628

Hartman O, Fauchald K (1971) Deep-water benthic polychaetous annelids off New England to Bermuda and other North Atlantic areas. Part II. Allan Hancock Monogr Mar Biol 6:1-327

Holthe T (1986) Polychaeta Terebellomorpha. Mar Invertebr Scand 7:1-194

Howson CM, Picton BE (1997) The species directory of the marine fauna and flora of the British Isles and surrounding seas. Ulster Museum and The Marine Conservation Society, Belfast and Ross-on Wye, Ulster Museum Publication No. 276

Hutchings P, Peart R (2000) A revision of the Australian Trichobranchidae (Polychaeta). Invertebr Taxon $14: 225-272$ CrossRef

Imajima M, Williams SJ (1985) Trichobranchidae (Polychaeta) chiefly from the Sagami and Suruga Bays, collected by R/V Tansei-Maru (Cruises KT-65/76). Bull Natl Sci Mus Tokyo 11(1):7-18

Jouin-Toulmond C, Hourdez S (2006) Morphology, ultrastructure and functional anatomy of the branchial organ of Terebellides stroemii (Polychaeta: Trichobranchidae) and remarks on the systematic position of the genus Terebellides. Cah Biol Mar 47:287-299

Kim I-H, Sikorski A, O’Reilly M, Boxshall GA (2013) Copepods associated with polychaete worms in European seas. Zootaxa 3651(1):1-62CrossRefPubMed

Levinsen GMR (1878) Om nogle parasitiske Krebsdyr, der snylter hos Annelider. Vidensk Medd Dansk Naturh Foren Kjobenhavn 1877:351-380

McIntosh WC (1885) Report on the Annelida Polychaeta collected by H.M.S. 'Challenger' during the years 1873-76. Rep. Sci. Res. Voyage of H.M.S. Challenger during the years 1873-76. Zoology 12:1-554

Michel C, Bhaud M, Boumati P, Halpern S (1984) Physiology of the digestive tract of the sedentary polychaete Terebellides stroemi. Mar Biol 83:17-31CrossRef

Muir AI (2011) A redescription of Unobranchus (Annelida: Terebellida: Trichobranchidae), with notes on the systematics of Trichobranchidae. It J Zool 78(suppl 1):140-147CrossRef

O’ Reilly M, Geddes D (2000) Copepoda. In: Foster-Smith J (ed) The Marine Fauna and Flora of the Cullercoats District: Marine Species Records for the North East Coast of England, vol 1. Dove Marine Laboratory Publication, Penshaw Press, Sunderland, pp 217-281

O’Reilly M (1991) A guide to polychaete-infesting copepods from British waters. Porcupine Newsl 5(3):63-70

O’Reilly M (1995a) A new genus of copepod (Copepoda: Poecilostomatoida) commensal with the maldanid polychaete Rhodine gracilior, with a review of the Family Clausiidae. J Nat Hist 29:47-64CrossRef 
O’Reilly M (1995b). Parasitic and commensal Copepoda. In: Mackie ASY, Oliver PG, Rees EIS (eds) Benthic biodiversity in the southern Irish sea. Studies in Marine Biodiversity and Systematics from the National Museum of Wales. BIOMAR Reports 1:62-69

O’Reilly M (1999) Notes on copepod parasites of polychaete worms in Scottish waters: Including the first UK records of the Californian copepod Spiophanicola spinosus Ho, 1984 (Poecilostomatoida: Spiophanicolidae). Glasg Nat 23(4):46-47

O’Reilly M (2000) Notes on copepod parasites of phyllodocid polychaete worms in Scottish waters; including the first UK records of the Mediterranean copepod Phyllodicola petiti (Delamare-Deboutteville \& Laubier, 1960). Glasg Nat 23(5):39-44

O’Reilly M (2015) Parasitic and commensal polychaetes (Fams. Arabellidae and Sphaerodoridae) and copepods (Fam. Saccopsidae) associated with lamella-worms (Terebellides spp.) in Scottish (and nearby) waters. Glasg Nat. (in press)

O’Reilly M, Nowacki S, Bell A (2011) New records of scaleworms and their allies (Polychaeta: Aphroditoidea and Pisionoidea), from the Clyde and Argyll Sea Area, with notes on parasitic copepods, commensal entoprocts and other epizoans. Glasg Nat 25(3):49-60

Parapar J, Hutchings P (2015) Redescription of Terebellides stroemii (Polychaeta, Trichobranchidae) and designation of a neotype. J Mar Biol Assoc UK 95:323-337CrossRef

Parapar J, Moreira J (2008) Revision of three species of Terebellides (Polychaeta: Trichobranchidae) described by C. Hessle in 1917 from the Southern Ocean. J Nat Hist 42(17-20):1261-1275CrossRef

Parapar J, Moreira J, Helgason GV (2011) Taxonomy and distribution of Terebellides (Polychaeta, Trichobranchidae) in Icelandic waters, with the description of a new species. Zootaxa 2983:1-20

Parapar J, Mikac B, Fiege D (2013) Diversity of the genus Terebellides (Polychaeta: Trichobranchidae) in the Adriatic Sea with the description of a new species. Zootaxa 3691:333-350CrossRefPubMed

Penry DL, Jumars PA (1990) Gut architecture, digestive constraints and feeding ecology of deposit -feeding and carnivorous polychaetes. Oecologia 82:1-11CrossRef

Sars M (1835) Beskrivelser og iagttagelser over nogle maerkelige eller nye i Havet ved den Bergenske Kyst levende Dyr af Polypernes, Acephalernes, Radiaternes, Annelidernes og Molluskernes Classer, med en kort Oversigt over de hidtil af Forfatteren sammesteds fundne Arter og deres Forekommen. Thorstein Hallagers Forlag hos Chr. Dahl, R.S., Bergen

Schüller M, Hutchings PA (2010) New insights in the taxonomy of Trichobranchidae (Polychaeta) with the description of a new Terebellides from Australia. Zootaxa 2395:1-16

Schüller M, Hutchings PA (2012) New species of Terebellides (Polychaeta: Trichobranchidae) indicate longdistance dispersal between western South Atlantic deep-sea basins. Zootaxa 3254:1-31 
Schüller M, Hutchings PA (2013) New species of Terebellides (Polychaeta: Trichobranchidae) from deep Southern Ocean. Zootaxa 3619:1-45CrossRefPubMed

Solís-Weiss V, Fauchald K, Blankestein A (1991) Trichobranchidae (Polychaeta) from shallow warm water areas in the Western Atlantic Ocean. Proc Biol Soc Wash 104(1):147-158

Uschakov PV (1955) Polychaeta of the Far Eastern Seas of the U.S.S.R. Keys to the Fauna of the U.S.S.R. published by the Zoological Institute of the Academy of Sciences of the U.S.S.R. Academy of Sciences of the U.S.S.R. Israel Program for Scientific Translations, Jerusalem

Williams SJ (1984) The status of Terebellides stroemi (Polychaeta; Trichobranchidae) as a cosmopolitan species, based on a worldwide morphological survey, including description of new species. In: Hutchings PA (ed) Proceedings of the First International Polychaete Conference, Sydney, Australia, 1984. The Linnean Society of New South Wales, Sydney, pp 118-142 